\title{
Pengaruh Pendekatan Open-Ended terhadap Kemampuan Penalaran Matematis Siswa SMP pada Materi Garis dan Sudut
}

\author{
${ }^{1}$ Suharni Arfan, ${ }^{2}$ In Hi. Abdullah, ${ }^{3}$ Asmar Bani \\ ${ }^{1,2,3}$ Program Studi Pendidikan Matematika Universitas Khairun
}

\begin{abstract}
ABSTRAK
Penelitian ini bertujuan untuk: 1) mendeskripsikan kemampuan penalaran matematis siswa pada materi garis dan sudut melalui pembelajaran dengan pendekatan Open-Ended; 2) mendeskripsikan peningkatan kemampuan penalaran matematis siswa pada materi garis dan sudut setelah pembelajaran denganpendekatan Open-Ended;3) mengetahui bahwa pendekatan Open-Ended berpengaruh terhadappeningkatan kemampuan penalaran matematis siswa pada materi garis dan sudut. Penelitian yang menggunakanmetode penelitian eksperimen semu dengandesain One Group Pretest-Posttest ini menjadikan seluruh siswa kelas VIII SMP Negeri 7 Kota Ternate sebagai populasi dan 20 siswa sebagai sampel. Teknik pengambilan sampel menggunakanpurposive sampling.Mendapatkan data penelitian ini digunakan teknik tes, observasi dan dokumentasi. Instrumen tes menggunakan 8 butir soal berbentuk essay tentang materi garis dan sudut, observasi menggunakan pedoman observasi. Data kemampuan penalaran matematis siswa yang diperoleh dianalisis secara deskriptif dan inferensial, hasil analisis mengatakan bahwa 1) kemampuan penalaran matematis siswa setelah penerapan pendekatan Open-Ended terdapat 3siswa $(15 \%)$ dalam kualifikasi gagal, 7siswa (35\%) dalam kualifikasi kurang, 4siswa $(20 \%)$ dalam kualifikasi cukup,3siswa (15\%) dengan kualifikasi baikdan 3 siswa(15\%) dengan kualifikasi memuaskan; 2) peningkatan kemampuan penalaran matematis siswa dengan interpretasi tinggi5 siswa (25\%) dan interpretasi sedang 15 siswa $(75 \%)$ secara keseluruhan peningkatan kemampuan penalaran matematis siswa dalam interpretasi sedang; 3) pembelajaran dengan pendekatan Open-Endeddapat memberikan pengaruh yang signifikan terhadap peningkatan kemampuan penalaran matematis siswa dalam mempelajari materi garis dan sudut.
\end{abstract}

Kata Kunci: Kemampuan Penalaran Matematis, Pendekatan Open-Ended, Garis dan Sudut

\section{PENDAHULUAN}

Pendidikan merupakan suatu kegiatan yang universal dalam kehidupan manusia. Menurut Riyanto (2009: 143) pendidikan merupakan kegiatan manusia untuk memanusiakan sendiri, yaitu manusia berbudaya. Pasal 1 ayat (1) Undang- 
Undang Nomor 20 Tahun 2003 tentang Sistem Pendidikan menjelaskan bahwa, pendidikan adalah usaha sadar dan terencana untuk mewujudkan suasana belajar dan proses pembelajaran agar peserta didik secara aktif mengembangkan potensi dirinya untuk memiliki kekuatan spiritual keagamaan, pengendalian diri, kepribadian, kecerdasan, akhlak mulia, serta keterampilan yang diperlukan dirinya, masyarakat, bangsa dan negara. Pendidikan adalah kata kunci untuk meningkatkan kesejahteraan dan martabat bangsa. Tak salah jika disebut pendidikan sebagai pilar pokok dalam pembangunan bangsa. Tinggi-rendah derajat suatu bangsa bisa dilihat dari mutu pendidikan yang diterapkannya.

Berdasarkan laporan Trends in International Mathematics and Science Study (TIMSS) tahun 2011, Indonesia berada pada peringkat ke 38 dari 45 negara peserta tes, dengan skor 386 dibawah skor rata-rata 500. Skor Indonesia turun 11 poin dari penilaian tahun 2007 yang pada saat itu Indonesia mendapat skor ratarata 397. Sedang data dari Program for International Student Assesment (PISA) tahun 2015 dalam kemampuan membaca, matematika, dan sains secara keseluruhan, posisi Indonesia berturut-turut berada pada peringkat 64, 63, dan 62 dari 72 negara peserta dengan skor 350. Hal ini menunjukkam bahwa kemampuan matematika siswa di Indonesia masih tergolong rendah. Setiadi, dkk. (Saputri dkk, 2017: 16) menyatakan bahwa salah satu faktor rendahnya hasil TIMSS 2011 yang dicapai oleh Indonesia dikarenakan kurang terlatihnya peserta didik dalam menyelesaikan soal-soal yang menuntut penalaran. Peserta didik Indonesia ratarata dapat menjawab benar soal-soal pada domain kognitif penalaran hanya sebesar 17\%, yang mana domain kognitif penalaran merupakan persentase terendah dari jawaban benar peserta didik Indonesia di samping domain pengetahuan yang sebesar $31 \%$ dan domain penerapan sebesar $23 \%$.

Berdasarkan hasil tes observasi dan hasil wawancara dengan guru mata pelajaran matematika pada siswa kelas VIII-B di sekolah SMP Negeri 7 Kota Ternate pada hari Sabtu, 03 Novemeber 2018. Informasi yang didapat yaitu sebagian besar siswa dianggap masih kesulitan dalam memahami pelajaran matematika dari berbagai materi pelajaran matematika, pembelajaran oleh guru hanya menggunakan satu model pembelajaran yakni model pembelajaran 
Discovery Learning, dimana guru mata pelajaran belum menggunakan model pembelajaran yang lain untuk mengajarkan kepada siswa. Peneliti kemudian membuat instrumen tes tentang perbandingan, bentuk aljabar dan materi garis dan sudut yang merupakan materi yang telah dipelajari siswa sebelumnya. Instrumen tes tersebut memuat aspek kemampuan pemahaman konsep matematis, kemampuan pemecahan masalah matematis dan kemampuan penalaran matematis. Berdasarkan hasil observasi tersebut, siswa cenderung mengalami kesulitan dalam menyelesaikan soal yang berkaitan dengan aspek penalaran matematis.

Upaya menyikapi rendahnya penalaran matematis siswa bisa ditempuh melalui pemilihan model pembelajaran. Pembelajaran yang diharapkan adalah dapat memberikan kesempatan yang luas kepada siswa untuk berfikir serta mengembangkan dan mengkomunikasikan gagasan serta informasi dengan menemukan sendiri atau berinteraksi. Pembelajaran yang dapat menumbuhkan aktifitas pembelajaran yang membimbing siswa dalam penemuan pertanyaan serta jawaban yang dihasilkan terhadapnya sehingga menyebabkan rasa puas atas keberhasilan menemukan jawaban dari permasalahan yang diajukan.

Mencapai tujuan pembelajaran diatas perlulah dicari alternatif pembelajaran yang dapat memberikan kesempatan kepada siswa untuk mengungkapkan ide/gagasan matematika secara optimal serta menumbuhkan penalaran sehingga siswa lebih berfikir dalam belajar matematika. Salah satu model pembelajaran yang diterapkan dalam proses pembelajaran matematika adalah pendekatan OpenEnded. Pendekatan pembelajaran Open-Ended merupakan salah satu alternatif pilihan pendidik dalam proses pembelajaran untuk mencapai tujuan yang telah ditetapkan.

Kemampuan penalaran matematis menurut Garner (Pawesti, 2017: 11) adalah kemampuan menganalisis, menggeneralisasi, mensistensis/mengintegrasikan, memberikan alasan yang tepat dan menyelesaikan masalah tidak rutin.Rohana (Sholiha Afif, 2016: 23) menjelaskan kemampuan penalaran matematis adalah kemampuan memahami ide matematika yang lebih dalam, mengamati dan menggali ide implisit, mengatur dugaan, analogi dan generalisasi, penalaran logis. 
Kemampuan penalaran matematis membantu siswa dalam menyimpulkan dan membuktikan suatu pernyataan, membangun gagasan baru, sampai pada menyelesaikan masalah-masalah dalam matematika.

Shimada (Ruslan dan Santoso, 2013: 140) mengemukakan pendekatan OpenEnded berawal dari pandangan bagaimana mengevaluasi kemampuan siswa secara objektif dan berpikir matematika tingkat tinggi. Supaya matematika dapat disenangi dan dipelajari oleh semua siswa, maka permasalahan tertutup (Closed Problem) yang menuntut satu jawaban yang benar hendaknya diganti dengan permasalahan terbuka (Open-Ended Problems). Lebih lanjut Shimada (Ruslan dan Santoso, 2013: 140) mengatakan pendekatan Open-Ended adalah suatu pendekatan pembelajaran yang dimulai dari pengenalan atau menghadapkan siswa pada masalah Open-Ended. Masalah Open-Ended adalah suatu permasalahan yang diformulasikan mempunyai banyak jawaban yang benar.

\section{METODE PENELITIAN}

Penelitian ini dilakukan di SMP N 7 Kota Ternate yang bertempat di JL. Siswa, Kecamatan Ternate Tengah Kota Ternate dan waktu pelaksanaannya pada bulan November 2018 sampai Juli 2019 Tahun Ajaran 2018/2019. Penelitian ini merupakan penelitian eksperimen semu (quasi eksperiment). Desain dalam penelitian ini adalah One-Group Pretest-Postest Design (Sugiyono, 2014: 110). Dimana sebelum perlakuan terlebih dahulu diberikan tes awal (pretest) dan setelah perlakuan diberikan tes akhir (posttest).

Jumlah siswa kelas VIII SMP Negeri 7 Kota Ternate adalah sebanyak 386 siswa. Subjek penelitian adalah seluruh siswa kelas VIII B SMP Negeri 7 Kota Ternate yang berjumah 20 siswa. Adapun pemilihan subjek pada penelitian ini menggunakan purposive sampling yaitu penentuan sampel dengan pertimbangan tertentu. Variabel dalam penelitian ini adalah kemampuan penlaran matematis yang diterapkan dengan pendekatan open-ended.

Pengumpulan data dalam penelitian ini menggunakan teknik tes. Tes yang digunakan berbentuk uraian yang terdiri dari 8 butir soal yang mencakup tiga indikator untuk melihat kemampuan penalaran matematis siswa. Tes tertulis ini 
untuk mengetahui kemampuan penalaran matematis siswa, yang meliputi pretest dan posttest. Pretest digunakan untuk mengetahui kemampuan awal siswa sebelum pembelajaran danPosttest digunakan untuk mengetahui kemampuan akhir kemampuan penalaran matematis siswa setelah pembelajaran dengan pendekatan Open-Ended.

\section{HASIL PENELITIAN DAN PEMBAHASAN}

Data kemampuan penalaran matematissiswa sebelum pembelajaran yang diperoleh skor rata-rata kelas sebesar37,03 dengan Skor minimum dan maksimum berturut-turutr9,38 dan 50,00. Hal ini memberikan gambar bahwa kemampuan penalaran matematis siswa pada materi garis dan sudut dalam kualifikasi gagal, sehingga perlu ditingkatkan melalui pembelajaran dengan pendekatan OpenEndedHasil tes akhir (posttest) diperoleh Skor rata-rata kelas sebesar71,56 dengan Skor minimumdan maksimum berturut-turut65,63 dan100,00. Hal ini menunjukkan bahwa kemampuan penalaran matematis siswa mengalami peningkatan.

\section{Kualifikasi Kemampuan Penalaran Matematis Siswa Setelah Pembelajaran Dengan Pendekatan Open-Ended}

Hasil klasifikasi data setelah diterapkan pendekatan Open-Ended untuk kemampuan penalaran matematis berdasarkan kriteria penalaran mtematis siswa dapat dilihat pada tabel berikut:

Tabel 1.Kualifikasi Kemampuan Penalaran Matematis Siswa SetelahPembelajaran denganPendekatan Open-Ended

\begin{tabular}{|c|c|c|c|c|}
\hline No & Tingkat penguasaan & Presentasi & Frekuensi & Kualifikasi \\
\hline 1 & $91 \%-100 \%$ & $15 \%$ & 3 & Memuaskan \\
\hline 2 & $81 \%-90 \%$ & $15 \%$ & 3 & Baik \\
\hline 3 & $71 \%-80 \%$ & $20 \%$ & 4 & Cukup \\
\hline 4 & $61 \%-70 \%$ & $35 \%$ & 7 & Kurang \\
\hline 5 & $\leq 60 \%$ & $15 \%$ & 3 & Gagal \\
\hline Jumlah & \multicolumn{5}{|c|}{$\mathbf{7 1 , 5 6}$} & $\mathbf{2 0}$ & \\
\hline Rata-rata & \multicolumn{5}{l}{} \\
\hline
\end{tabular}

Berdasarkan data pada tabel 1 di atas, kualifiikasi kemampuan penalaran matematis siswa sesudah diberikan perlakuan pembelajaran pendekatan Open- 
Endedpada materi garis dan sudut dapat dijelaskan bahwa sesudah pendekatan pembelajaran dengan pendekatan Open-Ended terdapat 3 siswa (15\%) dalam kualifikasi gagal, 7 siswa (35\%) dalam kualifikasi kurang, 4 siswa (20\%) dalam kualifikasi cukup, 3 siswa (15\%) dengan kualifikasi baik dan 3 siswa (15\%) dengan kualifikasi memuaskan.

\section{Peningkatan Kemampuan Penalaran Matematis Siswa Setelah}

\section{Pembelajaran Dengan Pendekatan Open-Ended}

Peningkatan kemampuan penalaran matematis siswa kelas VIII-B SMP Negeri 7 Kota Ternate dalam mempelajari materi garis dan sudut sebelum dan setelah pembelajaran baik secara individu dan klasikal.

Tabel 2. Peningkatan Kemampuan Penalaran Matematis Siswa Kelas VIII-B SMP Negeri 7 Kota Ternate Secara Individu Pada Materi Garis dan Sudut Melalui Pendekatan Open-Ended

\begin{tabular}{|c|c|c|c|}
\hline Interval & Frekuensi & Presentase & Interpretasi \\
\hline$\langle g\rangle \geq 0,70$ & 5 & $25 \%$ & Tinggi \\
\hline $0,30 \leq<g\rangle<0,70$ & 15 & $75 \%$ & Sedang \\
\hline
\end{tabular}

Berdasarkan data tabel di atas, secara individu peningkatan kemampuan penalaran matematis siswa kelas VIII-B SMP Negeri 7 Kota Ternatepada materi garis dan sudut melalui pendekatan Open-Endedterdapat 5 siswa (25\%) dengan interpretasi peningkatan tinggi dan 15 siswa (75\%) dengan interpretasi peningkatan sedang. Hal ini menunjukkan bahwa kemampuan siswa dalam penalaran matematis secara individu dikategorikan tinggi dan sedang.Peningkatan kemampuan penalaran matematis secara klasikal yang diperoleh dari proporsi rata-rata pretest dan posttest dijelaskan pada tabel 4.

Tabel 3.Peningkatan kemampuan penalaran matematis siswa Kelas VIII-B SMP Negeri 7 Kota Ternate Secara Klasikal Pada Materi Garis dan Sudut Melalui Pendekatan Open-Ended

\begin{tabular}{|c|c|c|c|}
\hline Rata-Rata Pretest & Rata-Rata Posttest & N-Gain & Interpretasi \\
\hline 37,03 & 71,56 & 0,60 & Sedang \\
\hline
\end{tabular}

Berdasarkan tabel $11 \mathrm{di}$ atas, menunjukkan bahwa nilai rata-rata pretest dan posttest yaitu kemampuan penalaran matematis sebelum dan setelah diterapkan pendekatan Open-Endedberturut-turut adalah 37,03 dan 71,56. Hasil perhitungan diperoleh peningkatan penalaran matematis siswa dengan 
menggunakan rumus $\mathrm{N}$-Gain secara klasikal yaitu 0,60 , dalam interpretasi peningkatan sedang. Artinya, peningkatan penalaran matematis siswa setelah diterapkan pendekatan Open-Endedsecara keseluruhan tergolong sedang.

Hasil penelitian yang diperoleh berdasarkan temuan-temuan peneliti dalam penelitian ini menggunakan pendekatan Open-Ended.sebagaimana diuraikan di atas, berikut ini pembahasannya:

\section{Kemampuan Penalaran Matematis Siswa Pada Materi Garis dan Sudut Setelah Diterapkan Pendekatan Open-Ended}

Hasil analisis data penelitian yang dilakukan bahwa pencapaian kemampuan penalaran matematis siswa yang mendapatkan pembelajaran dengan pendekatan Open-Endedpada materi garis dan sudut dalam kategori baik, cukup, kurang dan gagal, pencapaian tersebut tidak lepas dari akibat pembelajaran dengan pendekatan Open-Endedyang mengantarkan terciptannya aktivitas guru dan siswa dalam proses pembelajaran.

Kemampuan siswa dalam mengajukan dugaan matematika, menarik kesimpulan, menyusun bukti, memberikan alasan atau bukti terhadap kebenaran solusi, dan menarik kesimpulan dari pernyataan, dijelaskan berdasarkan kualifikasi baik, cukup, kurang dan gagal sebagai berikut.

1) Kemampuan penalaran matematis siswa dalam kualifikasi memuaskan

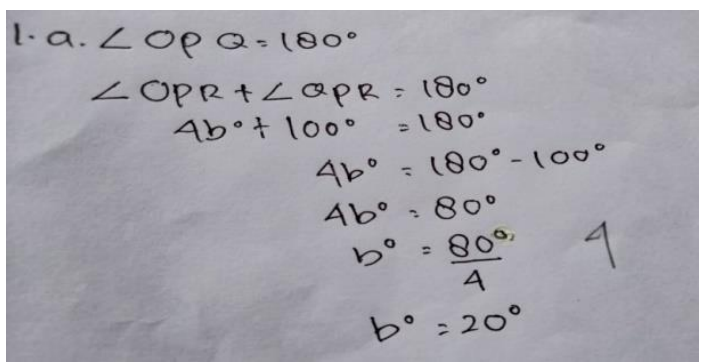

\section{Gambar 1.Hasil Pekerjaan SA5 pada Posttest}

Berdasarkan hasil pekerjaan siswa di atas, dapat dilihat bahwa siswa tersebut sudah mampu menjawab dengan benar soal dengan indikator mengajukan dugaan matematika, siswa mampu mengajukan dugaan matematika dengan benar, yaitu siswa menjumlahkan $\angle \mathrm{OPR}$ dan $\angle \mathrm{QPR}$ yang merupakan sudut lurus dengan jumlah $180^{\circ}$. Kemudian siswa tersebut mampu mencari nilai $b^{\circ}$ dari apa yang telah diketahui. Hal ini menunjukan bahwa penalaran matematis siswa dalam 
indikator mengajukan dugaan matematika berdasarkan proses matematika yang terlihat memuaskan.

2) Kemampuan penalaran matematis siswa dalam kualifikasi baik

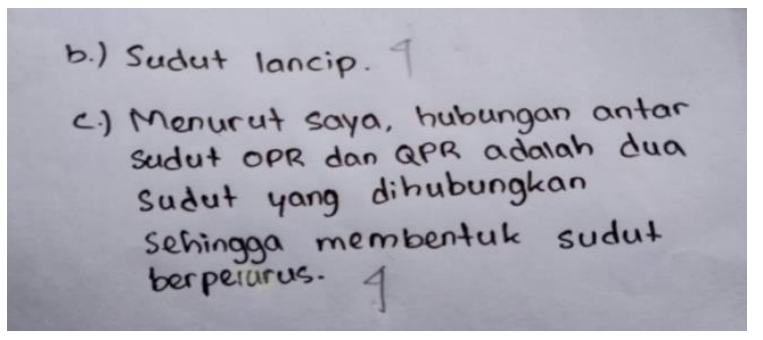

\section{Gambar 2.Hasil Pekerjaan SA4 pada Posttest}

Berdasarkan hasil pekerjaan di atas, siswa mampu mengajukan dugaannya sendiri dengan benar dan tepat. Hal ini menunjukan bahwa penalaran matematis siswa dalam indikator mengajukan dugaan matematika terlihat baik.

3) Kemampuan penalaran matematis siswa dalam kualifikasi cukup

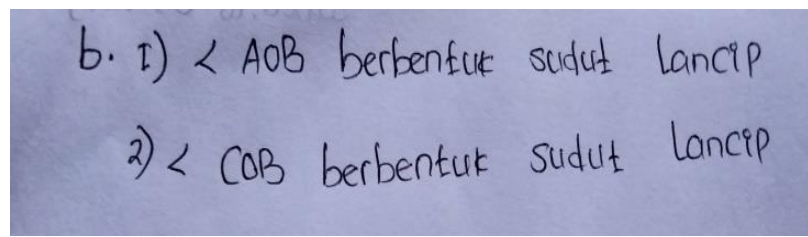

\section{Gambar 3.Hasil Pekerjaan SA2 pada Posttest}

Berdasarkan hasil pekerjaan di atas, siswa tidak mampu menarik kesimpulan dari pernyataan yang diberikan. Terlihat siswa hanya pernyataan menurut siswa itu sendiri.Yang diharapkan siswa dapat menarik kesimpulan dari pernyataan yang di berikan.Hal ini menunjukan bahwa penalaran matematis siswa n dalam indikator menarik kesimpulan dari pernyataan masih kurang.

4) Kemampuan penalaran matematis siswa dalam kualifikasi kurang

$$
\text { 2.) } \begin{aligned}
\angle 1+\angle 3 & +90^{\circ}=180^{\circ} \\
\angle 1+\angle 3 & =100^{\circ}-90^{\circ} \\
& =90^{\circ}
\end{aligned}
$$

\section{Gambar 4. Hasil pekerjaan SA15 pada Posttest}

Berdasarkan hasil pekerjaan di atas, siswa tidak mampu menyelesaikan soal nomor 2.Diharapkan siswa mampu menyusun bukti, memberikan alasan atau bukti terhadap kebenaran solusi, tetapi siswa tersebut tidak mampu dalam 
menyusun bukti terhadap kebenaran solusi. Hal ini menunjukan bahwa penalaran matematis siswa dalam indikator menarik kesimpulan, menyusun bukti, memberikan alasan atau bukti terhadap kebenaran solusi masih kurang.

5) Kemampuan penalaran matematis siswa dalam kualifikasi gagal

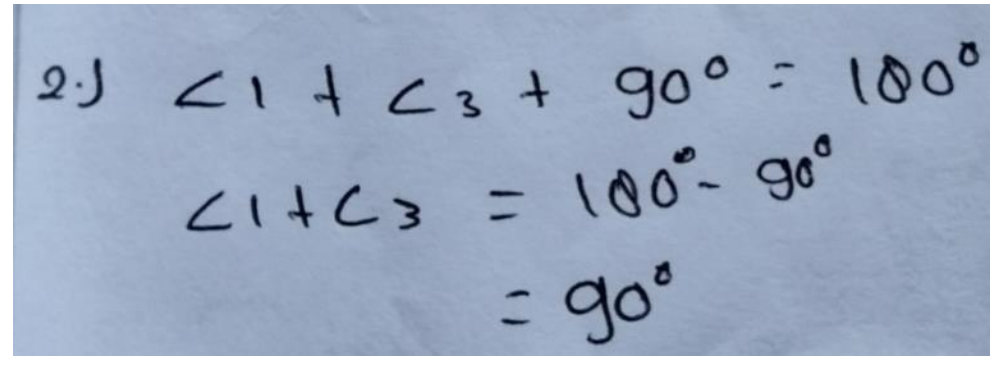

Gambar 5.Hasil pekerjaan SA15 pada Posttest

Berdasarkan hasil pekerjaan di atas, siswa tidak mampu menyelesaikan soal nomor 3a. Siswa tersebut tidak mampu membuat pernyataan matematika, siswa hanya menuliskan apa yang diketahui dan ditanyakan dari soal yang diberikan, serta siswa tersebut tidak dapat menarik kesimpulan dari pertanyataan. Hal ini menunjukan bahwa penalaran matematis siswa dalam indikator menarik kesimpulan dari pernyataan matematika masih kurang.

\section{Peningkatan Kemampuan Penalaran Matematis Siswa Pada Materi}

Garis dan Sudut Setelah Pembelajaran Dengan Pendekatan Open-Ended

Berdasarkan tabel 8, diperoleh bahwa nilai rata-rata tes awal (pretest) adalah 37,03 dan nilai rata-rata tes akhir (posttest) sebesar71,56. Hal ini menunjukkan bahwa kemampuan penalaran matematis siswa setelah menggunakan pendekatan Open-Ended terjadi peningkatan dibandingkan dengan sebelum menggunakan model pendekatan Open-Ended.Berdasarkan uji hipotesis yang dilakukan, diperoleh nilai sig. 0,000. Nilai tersebut kurang dari 0,05 (sig. < 0,05) sehingga dapat disimpulkan bahwa pembelajaran dengan pendekatan Open-Ended secara signifikan dapat berpengaruh terhadap peningkatan kemampuan penalaran matematis siswa pada materi garis dan sudut.

Berdasarkan hasil perhitungan $\mathrm{N}$-gain peningkatan kemampuan pemahaman matematis siswa secara keseluruhan berada pada interpretasi sedang dengan nilai rata-rata $N$-gain 0,60 . Menunjukan bahwa tujuan dari penelitian ini telah tercapai, yaitu terdapat pengaruh yang signifikan pembelajaran dengan pendekatan Open- 
Ended terhadap kemampuan penalaran matematis siswa kelas VIII-B SMP Negeri 7 Kota Ternate pada pokok bahasan garis dan sudut.Selanjutnya akan diuraikan pengaruhsebelum dan sesudah pembelajaran dengan pendekatan OpenEndedterhadap kemampuan penalaran siswa kelas VIII-B SMP Negeri 7 Kota Ternate berdasarkan indikator kemampuan penalaran.

a) Mengajukan dugaan matematika

Berikut hasil pretest pekerjaan siswa dalam mengajukan dugaan matematika garis dan sudut sebagai berikut:

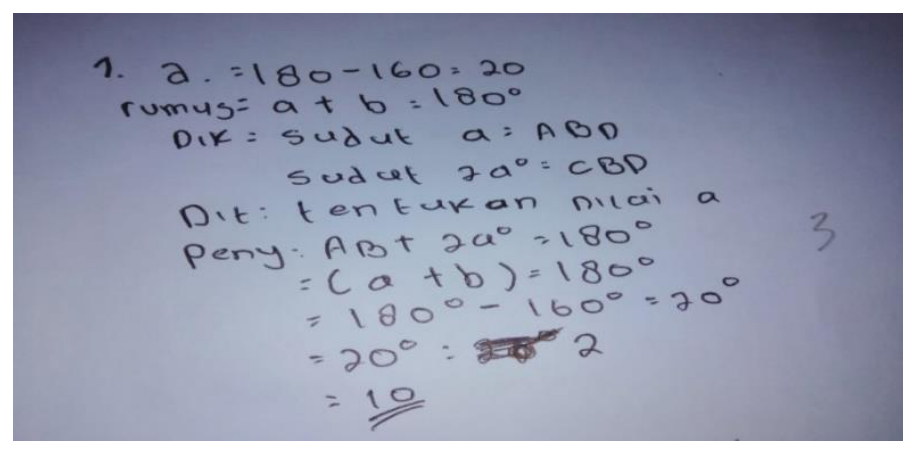

\section{Gambar 6. Hasil Kerja Siswa SA18 Sebelum Pembelajaran dengan Pendekatan Open-Ended}

Berdasarkan gambar diatas, terlihat bahwa siswa belum mampu mengajukan dugaan matematika untuk menyelesaikan soal yg diberikan. Jawaban akhir siswa sudah benar tapi cara penyelesaiannya siswa tersebut masih salah. Hal ini berarti bahwa kemampuan siswa dalam mengajukan dugaan matematika masih rendah.

Hasil kerja siswa dalam mengajukan dugaan matematika tentang sudut sebagai berikut:

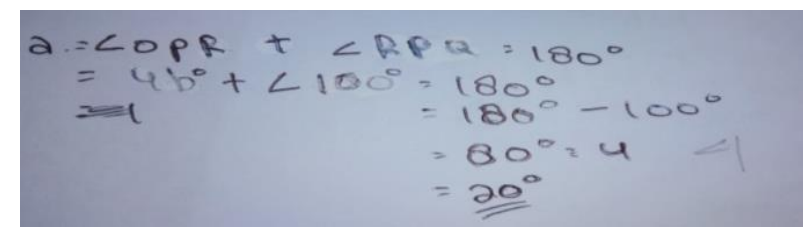

\section{Gambar 7. Hasil Kerja Siswa SA18 Setelah pembelajaran dengan Pendekatan Open-Ended}

Berdasarkan gambar diatas, terlihat bahwa siswa tersebut mampu menjawab soal dengan kemampuan mengajukan dugaan matematika yaitu dengan menjumlahkan kedua sudut yang membentuk sudut berpelurus untuk mencari nilai $b^{\circ}$. 
Berdasarkan hasil kerja siswa pada gambar 10dan gambar 11 menunjukkan bahwa terjadi peningkatankemampuan penalaran matematis siswa pada indikator mengajukan dugaan matematika. Artinya, pembelajaran dengan pendekatan OpenEnded dapat meningkatkan kemampuan penalaran matematis siswa.

b) menarik kesimpulan, menyusun bukti, memberikan alasan atau bukti terhadap kebenaran solusi

Berikut hasilkerja siswa dalam menarik kesimpulan, menyusun bukti, memberikan alasan atau bukti terhadap kebenaran solusi garis dan sudut sebagai berikut:

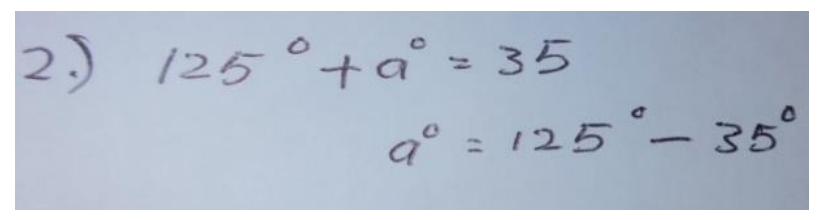

\section{Gambar 8.Hasil Kerja Siswa SA9 Sebelum pembelajaran dengan Pendekatan Open-Ended}

Berdasarkan gambar diatas, terlihat bahwa siswa belum mampu untuk menyusun bukti, apakah sudut $a^{\circ}$ dan $35^{\circ}$ saling berpenyiku atau tidak. Hal ini berarti bahwa kemampuan siswa dalam menarik kesimpulan, menyusun bukti, memberikan alasan atau bukti terhadap kebenaran solusi masih rendah.

Sedangkan hasil posttest pekerjaan siswa dalam melakukan menarik kesimpulan, menyusun bukti, memberikan alasan atau bukti terhadap kebenaran solusi garis dan sudut sebagai berikut:

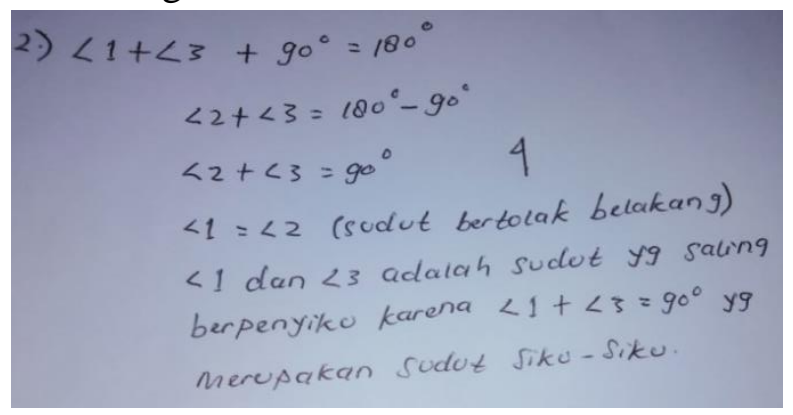

\section{Gambar 9. Hasil Kerja Siswa SA9 Setelah Pembelajaran dengan Pendekatan Open-Ended}

Berdasarkan gambar diatas, terlihat bahwa siswa tersebut mampu menjelaskan apakah sudut 1 dan sudut 3 saling berpenyiku serta memberikan alasan atau bukti terhadap kebenaran soulusi dengan benar. 
Berdasarkan hasil pekerjaan siswa pada gambar 12 dan gambar 13 menunjukan bahwa terjadi peningkatan kemampuan penalaran matematis siswa pada indikator menarik kesimpulan, menyusun bukti, memberikan alasan atau bukti terhadap kebenaran solusi.

- Menarik kesimpulan dari pernyataan

Berikut hasil pretest pekerjaan siswa dalam menarik kesimpulan dari pernyataan pada garis dan sudut sebagai berikut:

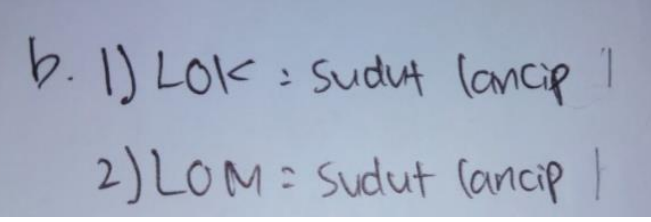

\section{Gambar 10. Hasil Kerja Siswa SA5 Sebelum Pembelajaran Dengan Pendekatan Open-Ended}

Berdasarkan gambar di atas, terlihat bahwa siswa mampu untuk memberikan pernyataan dengan benar tetapi siswa belum mampu menarik kesimpulan dari pernyataan yang diberikan. Hal ini berarti bahwa kemampuan siswa dalam menarik kesimpulan dari pernyataan terlihat masih rendah.

Sedangkan hasil posttest pekerjaan siswa dalam menarik kesimpulan dari pernyataan sebagai berikut:

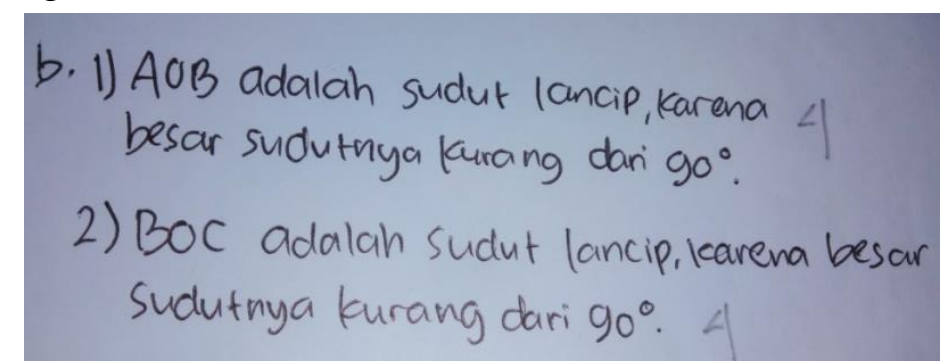

\section{Gambar 11. Hasil Kerja Siswa SA5 Setelah Pembelajaran DenganPendekatan Open-Ended}

Berdasarkan gambar di atas, terlihat bahwa siswa mampu untuk memberikan pernyataan dan menarik kesimpulan dari pernyataan tersebut dengan tepat dan benar.

Berdasarkan hasil pekerjaan siswa pada gambar 10 dan gambar 11 menunjukan bahwa terjadi peningkatan kemampuan penalaran matematis siswa pada indikator menarik kesimpulan dari pernyataan.Peningkatan kemampuan 
penalaran matematis siswa setelah pembelajaran dengan pendekatan Open-Ended dalam penelitian ini disebabkan karena pendekatan Open-Ended dapat membantu siswa untuk lebih aktif, berpikir intuitif, memperkuat konsep, bekerja sama dalam suatu kelompok sehingga proses belajar lebih terangsang dan melatih siswa belajar mandiri untuk menemukan pengetahuan yang baru berupa konsep dan prinsip. Seperti pendapat Anas (Yulanda, 2014: 63) bahwa dengan dibentukkan team atau kelompok dalam pembelajaran ini membuat siswa lebih semangat dalam belajar. Banyak ide-ide yang muncul ini tentunya akan semakin memperkaya pengetahuan dan pemahaman siswa sehingga siswa dapat meningkatkan penalaran matematis siswa. Dengan demikian peningkatan kemampuan penalaraan matematis siswa pada materi garis dan sudut setelah pembelajaran dengan pendekatan Open-Ended mengalami peningkatan dengan interpretasi sedang

Peningkatan kemampuan penalaran matematis siswa ini melalui beberapa tahap pembelajaran, dalam pembelajaran dengan menggunakan pendekatan OpenEnded, siswa dibagi menjadi beberapa kelompok, kemudian setiap kelompok bekerjasama menyelesaian soal yang di berikan dilanjutkan dengan persentasi tiap anggota kelompok.Berdasarkan hasil penelitian ini maka peneliti menyimpulkan bahwa dapat meningkatkan kemampuan penalaran matematis siswa kelas VIII-B pada materi garis dan sudut.

\section{Pengaruh Pembelajarandengan Pendekatan Open-Ended Terhadap kemamampuan Penalaran Matematis Siswa pada Materi Garis dan Sudut}

Pengaruh pembelajaran dengan pendekatan Open-Ended terhadap kemampuan penalaran matematis siswa pada materi garis dan sudut dilihat dari indikator pengaruh yaitu: jika nilai rata-rata kemampuan penalaran matematis siswa pada materi garis dan sudut setelah pembelajaran dengan pendekatan OpenEnded lebih tinggi dari sebelum pembelajaran dengan pendekatan Open-Ended.

Berdasarkan analisis data yang terdapat pada hasil penelitian menunjukkan bahwa: nilai rata-rata kemampuan penalaran matematis siswa pada materi garis dan sudut setelah pembelajaran dengan pendekatan Open-Ended 71,56. 
Sedangkan nilai rata-rata kemampuan penalaran matematis siswa pada materi garis dan sudut sebelum pembelajaran dengan pendekatan Open-Ended 37,03. Sehingga nilai rata-rata kemampuan penalaran matematis siswa setelah pembelajaran dengan pendekatan Open-Ended lebih tinggi dari kualifikasi nilai rata-rata kemampuan penalaran matematis siswa sebelum pembelajaran dengan pendekatan Open-Ended.

Berdasarkan perbedaan nilai rata-rata tersebut yang memenuhi kriteria pengaruh suatu pendekatan terhadap peningkatan kemampuan penalaran matematis siswa maka dapat disimpulkan bahwa terdapat pengaruh pembelajaran dengan pendekatan Open-Ended terhadap peningkatan kemampuan penalaran matematis siswa kelas VIII-B SMP Negeri 7 Kota Ternate pada materi garis dan sudut.

\section{KESIMPULAN}

Berdasarkan hasil penelitian, maka dapat disimpulkan bahwa:

1. Kemampuan penalaran matematis siswa kelas VIII-B SMP Negeri 7 Kota Ternate setelah diterapkan pendekatan Open-Endedpada materi garis dan sudut, khususnya mengajukan dugaan matematika, menarik kesimpulan, menyusun bukti, memberikan alasan atau bukti terhadap kebenaran solusi, menarik kesimpulan dari pernyataandiperoleh15\% kualifikasi memuaskan, $25 \%$ baik, $20 \%$ cukup, $35 \%$ kurang, dan kualifikasi gagalsebesar $15 \%$.

2. Peningkatan kemampuan penalaran matematis siswa kelas VIII-B setelah diterapkan pendekatan Open-Endedpada materi garis dan sudut secara individu sebanyak 5 siswa (25\%) dengan interpretasi tinggi dan 15 siswa (75\%) dengan interpretasi sedang, secara klasikal peningkatan kemampuan penalaran matematis dalam interpretasi sedang.

3. Pembelajaran dengan pendekatan Open-Ended berpengaruh terhadap peningkatan kemampuan penalaran matematis siswa kelas VIII-B pada materi garis dan sudut. 


\section{DAFTAR PUSTAKA}

AfifSholiha, A.M. 2016. Analisis Kemampuan Penalaran Matematis Ditinjau Dari Gaya Belajar Siswa Dalam Problem Based Learning (PBL). Skripsi, Universitas Negri Semarang, Semarang.Ario, M. 2016. Analisis Kemampuan Penalaran Matematis Siswa SMK Setelah Mengikuti Pembelajaran Berbasis Masalah. Jurnal Ilmiah Edu Research, Vol (5), 125-134.

Depdiknas. Undang-Undang RI No.20 tahun 2003, tentang Sistem Pendidikan Nasional.

Lestari, N., Hartono, Y., dan Purwoko. 2016. Pengaruh Pendekatan Open-Ended Terhadap Penalaran Matematika Siswa Sekolah Menengah Pertama Palembang. Jurnal Pendidikan Matematika, Vol (10), 82-97.

Pawesti, B.A. 2017. Kemampuan Penalaran Matematis dalam Menyelesaikan Soal Garis Singgung Lingkaran Ditinjau dari Gaya Belajar Siswa Kelas VIII di SMP N 1 Nanggulan Tahun Ajaran 2016/2017. Skripsi, Unversitas Sanata Dharma, Yogyakarta.

Riyanto, Y. 2009. Paradigma Baru Pembelajaran: Sebagai Referensi bagi Pendidik dalam Implementasi Pembelajaran yang Efektif dan Berkualitas. Jakarta: Kencana Prenada Media Group.

Ruslan, A.S., dan Santoso, B. 2013. Pengaruh Pemberian Soal Open-Ended Terhadap Kemampuan Penalaran Matematis Siswa. Jurnal Kreano, Vol (4), 138-150.

Saputri, I., Susanti, E., dan Aisyah N. 2017. Kemampuan Penalaran Matematis Siswa Menggunakan Pendekatan Metaphorical Thinking Pada Materi Perbandingan Kelas VIII di SMP N 1 Indralaya Utara. Jurnal Elemen, Vol (3), 15-24.

Sugiono. 2014. Metode Penelitian Pendidikan Pendekatan Kuantitatif, Kualitatif, dan $R$ \&D. Bandung: Alfabeta.

Yulanda, N. dkk. 2014. Pengaruh Model Pembelajaran Kooperatif Tipe Student Team Achievement Division (STAD) Terhadap Pemahaman Konsep Matematika Siswa Kelas VII SMPN 3 Padang. Skripsi. 